\title{
ARTICLE \\ Reduced sedation and increased ethanol consumption in knock-in mice expressing an ethanol insensitive alpha 2 subunit of the glycine receptor
}

\author{
S. Gallegos ${ }^{1}$, L. San Martin ${ }^{1}$, A. Araya ${ }^{1}$, D. M. Lovinger ${ }^{2}$, G. E. Homanics $\mathbb{D}^{3}$ and L. G. Aguayo ${ }^{1}$
}

\begin{abstract}
Previous studies have shown the presence of several subunits of the inhibitory glycine receptor (GlyR) in the reward system, specifically in medium spiny neurons (MSNs) of the nucleus Accumbens ( $\mathrm{Ac}$ ). It was suggested that GlyR a1 subunits regulate $\mathrm{nAc}$ excitability and ethanol consumption. However, little is known about the role of the a2 subunit in the adult brain since it is a subunit highly expressed during early brain development. In this study, we used genetically modified mice with a mutation (KR389-390AA) in the intracellular loop of the GlyR a2 subunit which results in a heteromeric a $2 \beta$ receptor that is insensitive to ethanol. Using this mouse model denoted knock-in a2 (KI a2), our electrophysiological studies showed that neurons in the adult nAc expressed functional KI GlyRs that were rather insensitive to ethanol when compared with WT GlyRs. In behavioral tests, the KI a2 mice did not show any difference in basal motor coordination, locomotor activity, or conditioned place preference compared with WT littermate controls. In terms of ethanol response, $\mathrm{Kl}$ a2 male mice recovered faster from the administration of ataxic and sedative doses of ethanol. Furthermore, $\mathrm{Kl}$ a2 mice consumed higher amounts of ethanol in the first days of the drinking in the dark protocol, as compared with WT mice. These results show that the a2 subunit is important for the potentiation of GlyRs in the adult brain and this might result in reduced sedation and increased ethanol consumption.
\end{abstract}

Neuropsychopharmacology (2021) 46:528-536; https://doi.org/10.1038/s41386-020-0689-9

\section{INTRODUCTION}

Glycine receptors (GlyRs) are the main inhibitory receptors in spinal cord and brain stem. They regulate several physiological functions such as, muscle tone, motor coordination, sensory processing, respiratory rhythms, and pain [1,2]. Four different a subunits and one $\beta$ have been reported and they can form homopentamer $(5 a)$ or heteropentamer $(3 a 2 \beta)$ receptors. The main GlyR subunit in the spinal synapsis of the adult CNS is a1 $[3,4]$. In addition, studies have reported the presence of GlyRs in upper brain regions, for instance, prefrontal cortex [5], dorsal raphe [6], hippocampus, amygdala, striatum [7, 8], and nucleus Accumbens (nAc) $[9,10]$.

The $\mathrm{nAc}$ is a key region in the reward system and important in the regulation of natural rewarding stimuli and also drugs of abuse such as ethanol [11]. The $\mathrm{nAc}$ receives dopaminergic innervation from the ventral tegmental area and dense excitatory inputs from the hippocampus, amygdala, and prefrontal cortex [12]. Several studies have implicated the activation of GlyRs in the regulation of dopamine levels in the nAc [13-15], and in ethanol consumption [16]. In addition, it was recently reported that different GlyR subunits are expressed in the nAc of rats and mice $[9,17]$, and that the a1 subunit regulated the excitability of MSNs together with ethanol consumption and preference [18]. However, little is known about the role of the GlyR a2 subunit in the adult brain. This subunit was originally described as important in early stages of development of the central nervous system. It is highly expressed in embryonic and neonatal rodents and is later replaced with $\alpha 1$ or $\alpha 1 \beta$ subunits in the spinal cord of juvenile and adults rodents [19-21], however, $\alpha 2 \beta$ has been reported in forebrain areas, including the $\mathrm{nAc}$ in adult brain $[9,17]$. A study using $\mathrm{KO} \alpha 2$ mice found that the a 2 subunit was important in cortical neuronal migration during embryogenesis [22]. Although the a2 $\mathrm{KO}$ mice survive, they show deficits in short and long term recognition memory and have impaired long term potentiation in prefrontal cortex when compared with WT mice [23]. Another study using KO a2 adult mice reported reduced ethanol intake and aversion [24]. However, studies that utilize global KO mice are potentially confounded by the effects of developmental compensation. This is especially true for genes expressed embryonically like the GlyR a2 subunit. Therefore, taking the above studies into consideration and the evidence that a 2 GlyR mRNA is present in nAc [9], we decided to generate a new mouse model to analyze if this subunit has a role in regulating the activation of the nAc when ethanol is present and if this has an impact in ethanol related behaviors including consumption.

Hence, we generated a new mouse model denoted knock-in a2 ( $\mathrm{KI}$ a2). These mice have arginine 389 and lysine 390 mutated to alanines (KR389-390AA) in the large intracellular loop (LIL) of the a2 GlyR subunit. Previous studies identified that basic amino acids in the LIL of the GlyR a1 subunit (KK385-386) are important for

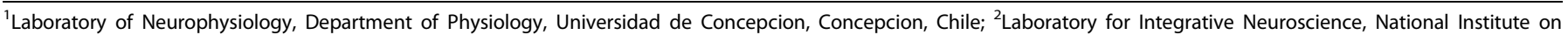

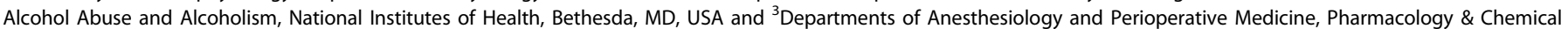
Biology, and Neurobiology, University of Pittsburgh, Pittsburgh, PA, USA

Correspondence: L. G. Aguayo (laguayo@udec.cl)

Received: 11 December 2019 Revised: 20 March 2020 Accepted: 23 April 2020

Published online: 1 May 2020 
ethanol potentiation mediated by $G \beta Y[25,26]$. And these residues correspond to the ones found in the LIL of the GlyR a2 subunit (KR389-390) [27]. The KR389-390AA mutation produces an a2 $\beta$ heteromeric GlyR that responds normally to glycine but is insensitive to ethanol. Because these mutant receptors respond normally to their endogenous ligand, no concerns about developmental compensation should arise.

In this study, we performed electrophysiological recordings in medium spiny neurons (MSN), the main neurons of $n A c$, in brain slices containing the $\mathrm{nAc}$ and in acute dissociated neurons from the $\mathrm{nAc}$ in $\mathrm{KI}$ a2 mice to test glycine and ethanol sensitivity in this brain region, and also to examine excitability changes in the $\mathrm{nAc}$ in the presence of ethanol. Using behavioral tests, we studied the locomotor activity of the $\mathrm{KI}$ a2 mice compared with WT mice in control conditions and after administration of high doses of ethanol, and we also performed ethanol consumption and preference tests. The results suggest that the a2 subunit of the GlyR is important in mediating the inhibitory tone in the nAc and has a role in recovery after ethanol administration, as well as in ethanol binge consumption.

\section{MATERIALS AND METHODS}

Animals

Animal care and experimental protocols for this study were approved by the Institutional Animal Care and Use Committees at the University of Concepción and the University of Pittsburgh, and followed the guidelines for ethical protocols and care of experimental animals established by $\mathrm{NIH}$ (National Institutes of Health, Maryland, USA). Female and male mice from 6 to 8 weeks of age were used for electrophysiology experiments, and mice of 10-12 weeks for behavior assays. Mice were housed in groups of 2-4 mice on a 12-h light/dark cycle and given food and water ad libitum.

Generation of the $\mathrm{KI}$ a2 mouse

Knock-in mice (KI) harboring the KR389-390AA substitutions in the Glra2 gene were created with CRISPR/Cas9 gene editing (see Supplemental Fig. 1). Briefly, a tru-sgRNA [28], in vitro transcribed Cas9 mRNA, and a 130 nucleotide single stranded repair template (Ultramer Oligonucleotide, Integrated DNA Technologies, Inc., Coralville, IA) were microinjected into $(57 \mathrm{BL} / 6 \mathrm{~J}$ zygotes to create founder mice as described in the literature [29-32]. One founder harbored all a $2 \mathrm{KI}$ mutations on one allele and a 13 bp deletion on the other allele. This founder was screened for off target mutations at the top 9 sites predicted by Benchling.com; none were found to be mutated (data not shown). This founder was mated to C57BL/6J females and F1 offspring heterozygous for only the $\mathrm{KI}$ mutations were obtained. Heterozygous breeding pairs were used to produce wild type and homozygous KI littermates for analysis.

In this study, mice are referred to as wild type (WT) C57BL/6J (without the mutation) and KI a2 (KR389-390AA mutation in the a2 subunit). All mice were genotyped using the Sigma Extract-NAmp Tissue PCR Kit on tail genomic DNA (Sigma \#XNAT2) and conventional polymerase chain reaction (PCR) with the following primers: F: 5'-GGGTCACTGCCTCCAAATGA; R: 5'-GAAACCCCACCC TCGTGATT. After PCR, all genotypes had a band at $362 \mathrm{bp}$. Restriction enzyme analysis with Mfel was done to distinguish genotypes. Digestion with Mfel produced the following genotype results on a $1.5 \%$ agarose gel electrophoresis, WT: 362 bp band; Heterozygote: 362 bp, 242 bp and 120 bp bands; KI a2: 242 bp, 120 bp bands.

\section{Preparation of brain slices}

Coronal brain slices containing the nAc were prepared immediately after excision and placement of the brain in ice-cold cutting solution (in mM: sucrose $194, \mathrm{NaCl} 30, \mathrm{KCl} 4.5, \mathrm{MgCl}_{2} 1, \mathrm{NaHCO}_{3}$
26, $\mathrm{NaH}_{2} \mathrm{PO}_{4}$ 1.2, Glucose 10, saturated with $95 \% \mathrm{O}_{2}$ and $5 \% \mathrm{CO}_{2}$ and adjusted to $\mathrm{pH}$ 7.4). The brain was cut and glued to the chilled stage of a VT1200S vibratome (Leica, Germany), and sliced to a thickness of $300 \mu \mathrm{m}$. Slices containing the nAc were transferred to aCSF solution (in mM: $\mathrm{NaCl} 124, \mathrm{KCl} 4.5, \mathrm{MgCl}_{2} 1, \mathrm{NaHCO}_{3} 26$, $\mathrm{NaH}_{2} \mathrm{PO}_{4}$ 1.2, Glucose $10, \mathrm{CaCl}_{2}$ 2, saturated with $95 \% \mathrm{O}_{2}$ and $5 \%$ $\mathrm{CO}_{2}$ at $32{ }^{\circ} \mathrm{C}$ and adjusted to $\mathrm{pH} 7.4$ and $\left.315-320 \mathrm{mOsm}\right)$. Brain slices were allowed to rest in $\mathrm{O}_{2}$-perfused aCSF at $32^{\circ} \mathrm{C}$ for at least $1 \mathrm{~h}$ before recording or enzymatic treatment for dissociation.

\section{Preparation of acutely dissociated neurons}

Acutely dissociated neurons were prepared from brain slices of mice of 6-8 weeks old. The $\mathrm{nAc}$, including the core and shell region but not the fascicle of the anterior commissure, was dissected from the brain slices and incubated for 30 min with 0.45 $\mathrm{mg} / \mathrm{ml}$ pronase (Calbiochem/EMD Bioscience, Darmstadt, Germany) in aCSF $\left(95 \% \mathrm{O}_{2} / 5 \% \mathrm{CO}_{2}\right)$ at $37^{\circ} \mathrm{C}$. Accumbal neurons were dissociated by mild mechanical trituration (10 times each with a 1000 and $200 \mu \mathrm{l}$ micropipette and with a fire polished self-drawn glass-pipette) in trituration buffer (in $\mathrm{mM}: \mathrm{NaCl} 20, \mathrm{~N}$-methyl-Dglucamine (NMG) 130, $\mathrm{KCl} 2.5, \mathrm{MgCl}_{2}$ 1, HEPES 10, Glucose 10, adjusted to $\mathrm{pH} 7.4$ and $340 \mathrm{mOsm})$. Neurons were allowed to settle for 15-20 min before recording in a $35-\mathrm{mm}$ diameter culture dish (Nunc ThermoFisher Scientific).

\section{Electrophysiology}

Recordings in brain slices and in dissociated neurons, were made from slices of both male and female WT and KI a2 mice. No noticeable differences were found in the glycinergic properties between male and female mice; therefore, these data was pooled together.

\section{Recordings in brain slices}

Acute brain slices containing the $\mathrm{nAc}$ were transferred to the recording chamber with aCSF solution saturated with $95 \% \mathrm{O}_{2}$ and $5 \% \mathrm{CO}_{2}$ at $30-32{ }^{\circ} \mathrm{C}$. The slices were observed in a DIC-IR microscope using $\times 10$ and $\times 40$ objectives (Nikon Eclipse FN1, Japan) and perfused with oxygenated aCSF at $2 \mathrm{ml} / \mathrm{min}$ at $30-32{ }^{\circ} \mathrm{C}$. Patch pipettes with a resistance of $4-5 \mathrm{M} \Omega$ were prepared from filament containing borosilicate micropipettes (World Precision Instruments, Florida, USA) using a P-1000 micropipette puller (Sutter Instruments, California, USA).

For excitability analysis, current-clamp recordings were made using an internal solution of potassium gluconate (in $\mathrm{mM}: 120$ KGluc, $10 \mathrm{KCl}, 10$ HEPES, 10 BAPTA, 2 MgATP, $0.5 \mathrm{NaGTP}$, adjusted to $\mathrm{pH} 7.4$ and $305 \mathrm{mOsm})$. As previously described [18] MSNs of the nAc were recorded in the whole-cell mode and action potentials (AP) were evoked with current injections of $0-400 \mathrm{pA}$ and a duration of $200 \mathrm{~ms}$. The number of AP was evaluated before and after perfusion with ethanol and STN in aCSF. For the recording, signals were captured using an Axopatch 200B amplifier (Axon Instruments, California, USA), recorded and stored on a personal computer using a 1322A Digidata (Axon Instruments) and analyzed with Clampfit 10.1 (Axon Instruments).

\section{Recordings in dissociated neurons}

Dissociated neurons from the $\mathrm{nAc}$ were examined in the voltageclamp configuration at $-60 \mathrm{mV}$ and at room temperature. The glycine-evoked current was recorded using an internal solution containing (in mM): $120 \mathrm{KCl}, 4.0 \mathrm{MgCl}_{2}, 10$ BAPTA, $0.5 \mathrm{NaGTP}$ and 2.0 MgATP (pH 7.4, 290-310 mOsmol). The external solution contained (in mM) $150 \mathrm{NaCl}, 2.5 \mathrm{KCl}, 2.5 \mathrm{CaCl}_{2}, 1.0 \mathrm{MgCl}_{2}, 10$ glucose and 10 HEPES (pH 7.4, 315-320 mOsm). Neurons were perfused with increasing concentrations of glycine $(1-1000 \mu \mathrm{M})$ to obtain a concentration-response curve. For ethanol potentiation, the $\mathrm{EC}_{10}$ of glycine $(15 \mu \mathrm{M})$ was used to evoke the current in the presence or absence of $10-100 \mathrm{mM}$ ethanol. 
530

Behavioral characterization

Male and female mice were used for the studies and the data were presented separately, except in Supplemental Fig. 6B where male versus female $\mathrm{KI}$ a2 were compared. All mice were between 10 and 12 weeks of age at the time of testing.

\section{Open field assay}

Mice were tested for basal locomotor activity in a modified open field assay using a video tracking system (ANY-maze, Stoelting Co.). WT and $\mathrm{KI}$ a2 mice were placed into the $50 \times 50 \mathrm{~cm}$ test area and were allowed to freely explore the chamber for $20 \mathrm{~min}$. The distance traveled every $5 \mathrm{~min}$, and the time spent in the center and the corners of the box was recorded.

\section{Accelerating rotarod}

Basal motor skill and coordination performance was tested in mice using an accelerating rotarod assay. Briefly, mice were placed on a rotating rod (IITC, Life Science). The rotarod began accelerating from 4 to $40 \mathrm{rpm}$ in $120 \mathrm{~s}$, and the latency to fall was recorded. Each mouse was tested five times on day 1, and 10 times on day 2.

\section{Fixed-speed rotarod}

The effects of ethanol on motor coordination were analyzed with the fixed-speed rotarod test. Mice were trained for 3 days on a fixed-speed rotarod (IITC, Life Science) at $8 \mathrm{rpm}$ to a maximum time of $120 \mathrm{~s}$. The third day mice were injected i.p. with 2 grams of ethanol per kilogram of weight $(2 \mathrm{~g} / \mathrm{kg})$, and tested every $15 \mathrm{~min}$ post injection (until $90 \mathrm{~min}$ ). The latency to fall was registered recorded.

Loss of righting reflex (LORR)

This assay was performed to assess the response of mice to a sedative concentration of ethanol. Mice were injected i.p. with 3.5 $\mathrm{g} / \mathrm{kg}$ ethanol, and when they became ataxic, they were placed in the supine position in V-shaped plastic troughs until they were able to right themselves three times within $30 \mathrm{~s}$. The onset of LORR was defined as the time from the injection until the mice lost the righting reflex. The duration of LORR was defined as the time when mice were placed in the supine position until the mice regained their normal prone position. During all LORR assays, normothermia was maintained with the aid of a heat lamp.

Drinking in the dark

The protocol that we used has been previously described [33, 34]. Briefly, the test took place $2 \mathrm{~h}$ after the dark cycle began. WT and $\mathrm{KI}$ a2 mice had access to a $15 \%(\mathrm{v} / \mathrm{v})$ ethanol solution and were able to drink for $2 \mathrm{~h}$ (day $1-3$ ) and $4 \mathrm{~h}$ (4th day). The bottles with a steel ball sipper containing the ethanol solution were weighed before and after the test. Ethanol consumption was registered recorded as grams of ethanol per kilogram of body weight $(\mathrm{g} / \mathrm{kg} /$ $2-4$ h).

\section{Blood ethanol concentration}

Blood samples $(20-50 \mu \mathrm{L})$ from WT and $\mathrm{KI}$ a2 mice were collected from the facial vein, 10 min after the drinking in the dark (DID) test on day 1 or 4 . Whole blood samples were spun-down in a centrifuge $(10000 \mathrm{rpm} \times 10 \mathrm{~min})$, and blood ethanol concentration (BEC) was determined in serum using an Analox AM1 Alcohol Analyzer (Analox Instruments Limited, UK). Also BEC samples were analyzed $1 \mathrm{~h}$ after the i.p. injection of 2 or $3.5 \mathrm{~g} / \mathrm{kg}$ ethanol to rule out differences in pharmacokinetics of ethanol in WT and KI a2 mice.

\section{Conditioned place preference}

This behavioral test is a Pavlovian conditioning paradigm primarily used to measure reward and motivation for substances or drugs of abuse [35]. The place-conditioning chambers $(33 \times 27 \times 20 \mathrm{~cm})$ were located in individual, ventilated, light and sound-attenuating enclosures and separated by a transparent wall. The conditioning chamber was placed over a floor made of two different textures. The positive stimulus floor (Cs+) consisted of a wire mesh $0.6-\mathrm{cm}$ grid. The negative stimulus floor (Cs-) was made with a $0.1-\mathrm{cm}$ grid. Mice were handled and habituated to a sham injection procedure, and were allowed to freely explore both chambers (day 1 for $15 \mathrm{~min}$ ). Twenty-four hours after habituation, the first conditioning session was initiated. CPP conditioning trials were performed for eight sessions. In the conditioning trials, the boxes were separated by a wall. Each mouse was weighed and injected i. p. with ethanol $(2.0 \mathrm{~g} / \mathrm{kg})$ (if $\mathrm{Cs}+$ trial) or $0.9 \%$ saline (if $\mathrm{Cs}-$ trial) paired with a different floor and chamber for $10 \mathrm{~min}$. Finally, $24 \mathrm{~h}$ after the final conditioning session (day 12), mice were injected i.p. with $0.9 \%$ saline, and placed in the center of the box without the wall to record the test activity in a 30-min preference session. The time spent in each side of the chamber was detected by infrared video recording. Preference test video was analyzed using tracking video software ANY-maze (Stoelting Co.) as mean time on each grid.

\section{Statistical data analysis}

Statistical analyses were performed using the two-tailed paired or unpaired Student $t$ tests. Data with more than two groups or factors were analyzed by one-way or two-way ANOVA test followed by a Bonferroni post hoc test using Origin 6 (Microcal, Inc., Massachusetts, USA) or GraphPad Prism 6 Software. Data are shown as mean \pm SEM. n.s. not significant, ${ }^{*} p<0.05,{ }^{* *} p<0.01$, ${ }^{* * *} p<0.001$.

\section{RESULTS}

The KR-AA mutation did not impair GlyRs activation with glycine in the $\mathrm{nAc}$ of the $\mathrm{KI}$ a2 mice

To determine if the KR389-390AA mutation in the a2 GlyR altered the activation of this receptor, we performed electrophysiological recordings in acutely dissociated neurons from nAc of the $\mathrm{KI}$ a2 mouse. Supplemental Fig. 2A shows evoked currents with increasing concentrations of glycine $(1-1000 \mu \mathrm{M})$. We obtained the following $\mathrm{EC}_{50}$ values from the glycine concentration-response curves: $31 \pm 4 \mu \mathrm{M}$ glycine for $\mathrm{Kl}$ a2 and $56 \pm 2 \mu \mathrm{M}$ for WT $\mathrm{nAc}$ $\left(t_{(28)}=3.021, p=0.0053\right.$, unpaired Student $t$ test, $n=15$ for KI a2 and $n=15$ for WT, Fig. S2B). Although the glycine curve in the KI a2 mice was displaced to the left, values for current density and maximum current elicited with $1000 \mu \mathrm{M}$ glycine did not differ between the $\mathrm{KI}$ a2 and WT mice $\left(t_{(39)}=0.279, p=0.7817\right.$, unpaired Student $t$ test for current density; $t_{(40)}=0.09553, p=$ 0.9244 , unpaired Student $t$ test for maximum current, $n=19 \mathrm{KI}$ a2 and $n=23$ for WT; Fig S2C, D). This suggests that the mutation does not affect the receptor expression or activation with its main ligand.

Ethanol potentiation is reduced in the $\mathrm{nAc}$ of $\mathrm{KI}$ a2 mice We next evaluated the ethanol sensitivity of GlyRs in acutely dissociated neurons from the $\mathrm{nAc}$ of $\mathrm{KI}$ a2 mice with different concentrations of ethanol. Figure 1 a shows representative traces of evoked glycinergic currents in $\mathrm{nAc}$ from $\mathrm{KI}$ a2 mice and the effects of 10,50, and $100 \mathrm{mM}$ ethanol. As a comparison, only the current response for a high concentration of ethanol $(100 \mathrm{mM})$ is shown for nAc of WT mice (Fig. 1b). The comparative analysis done in $\mathrm{nAc}$ from both genotypes revealed a reduced potentiation produced by the three concentrations of ethanol tested in the $\mathrm{KI}$ a2 mouse (Fig. 1c). In WT mice, ethanol potentiated the current by $42 \pm 7 \%$ at $10 \mathrm{mM}, 67 \pm 11 \%$ at $50 \mathrm{mM}$ and $78 \pm 12 \%$ at $100 \mathrm{mM}$; however, in $\mathrm{nAc}$ from $\mathrm{KI}$ a2 mice, the potentiation was only $15 \pm 5 \%(10 \mathrm{mM}), 23 \pm 4 \%(50 \mathrm{mM})$ and $34 \pm 5 \%(100 \mathrm{mM})$ $\left(F_{(1,111)}=45.40, p=0.0001\right.$, Two-way ANOVA and Bonferroni post hoc test ${ }^{*} p<0.05,{ }^{* * *} p<0.001 ; n=28 \mathrm{KI}$ a2 and $\left.n=13 \mathrm{WT}\right)$. Scatter graphs in Fig. 1d and e show that every cell recorded in 
A)

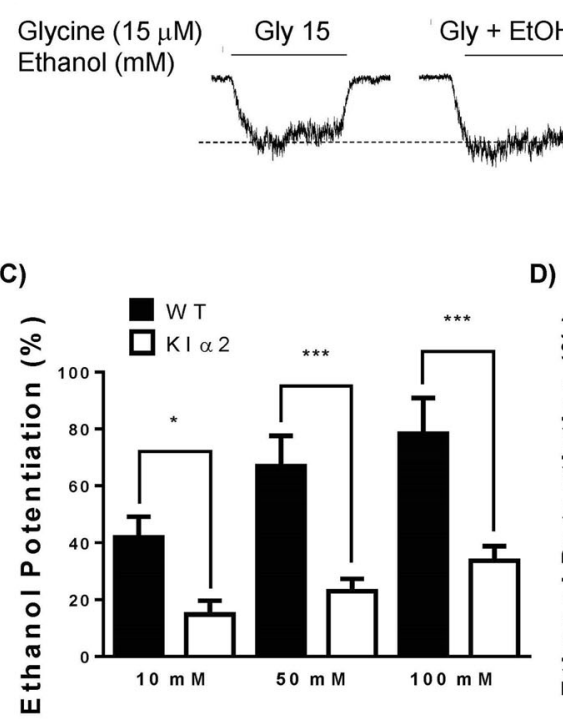

$\mathrm{KI} \alpha 2$

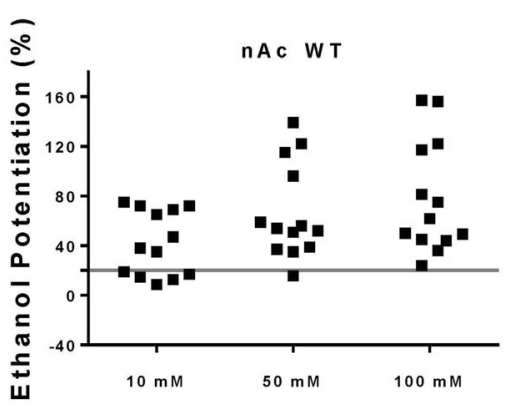

B)

WT

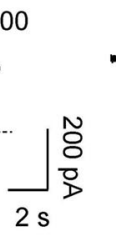

E)
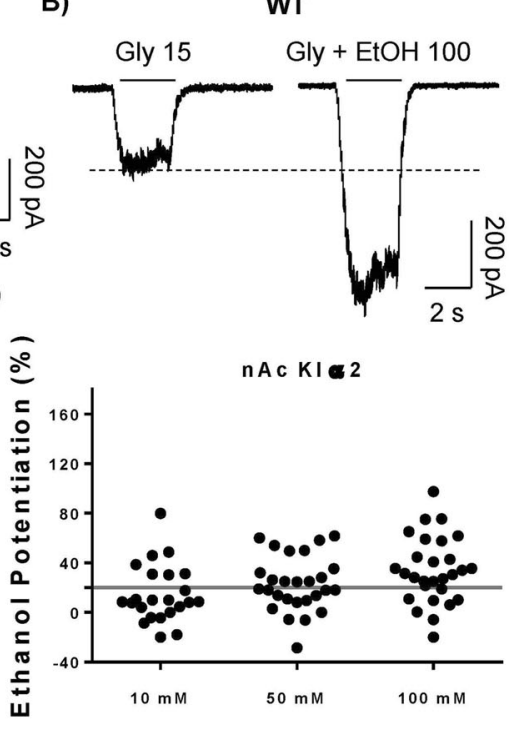

Fig. 1 Ethanol potentiation is reduced in neurons from $\mathbf{n A c}$ of $\mathbf{K I} \mathbf{a 2}$ mice. a Representative traces of evoked glycinergic currents with an $\mathrm{EC}_{10}$ of glycine $(15 \mu \mathrm{M})$ in the presence of increasing concentrations of ethanol $(10-100 \mathrm{mM})$ in $\mathrm{nAc}$ of $\mathrm{Kl} \alpha 2 \mathrm{mice}$. $\mathbf{b}$ Representative traces of evoked glycinergic currents in the presence of $100 \mathrm{mM}$ ethanol in nAc of WT mice. c Graph summarizes the percentage of potentiation of the glycinergic current for 10,50 and $100 \mathrm{mM}$ of ethanol in nAc from WT and KI $\alpha 2$ mice. d-e Scatter graph for the percentage of potentiation of the glycinergic current by ethanol in the WT and KI $\alpha 2$ mice, respectively. Higher potentiation is found in nAc of WT mice compared with KI $\alpha 2$. $n=28$ for KI $\alpha 2$ and $n=13$ for WT. Data are mean \pm SEM, Two-way ANOVA and Bonferroni post hoc test, ${ }^{*} p<0.05,{ }^{* * *} p<0.001$.

the nAc from WT mice was potentiated with 50 and $100 \mathrm{mM}$ ethanol, nonetheless, just $48 \%$ of the accumbal neurons from $\mathrm{KI}$ a2 showed potentiation with $50 \mathrm{mM}$, and $71 \%$ with $100 \mathrm{mM}$ ethanol. These results support the notion that the a2 subunit is present in the $\mathrm{nAc}$, because in this mouse model the mutation should inhibit the potentiation by ethanol only in neurons where the a2 subunit is expressed.

Neuronal excitability was not affected by ethanol in $\mathrm{nAc}$ of $\mathrm{KI}$ a2 mice

It was previously shown that application of $100 \mathrm{mM}$ ethanol decreases the excitability of WT accumbal neurons, an effect that was mediated by the GlyR a1 subunit [18]. The reduced GlyR potentiation by ethanol in the $\mathrm{nAc}$ of $\mathrm{KI}$ a2 mice was confirmed by studying the firing of action potentials (AP). We analyzed the number of APs and the effect of $100 \mathrm{mM}$ ethanol in brain slices of nAc from WT and KI a 2 mice. Figure $2 a, b$ show the APs elicited with $200 \mathrm{pA}$ for $200 \mathrm{~ms}$, in control condition, in the presence of $100 \mathrm{mM}$ ethanol and with the co-application of ethanol and $4 \mu \mathrm{M}$ STN, a potent antagonist of GlyRs, in nAc of KI $\mathrm{a} 2$ and WT, respectively. The graph in Fig. $2 \mathrm{c}$ shows that ethanol caused a reduction of $36 \pm 7 \%$ in APs only in the $n A C$ of WT mice and did not altered the number of APs recorded in $\mathrm{nAc}$ of $\mathrm{KI}$ a2 mice (reduction of $2 \pm 8 \%)\left(t_{(16)}=3.153, p=0.0062\right.$, unpaired Student $t$ test, $n=10$ for KI a2 and $n=8$ for WT mice). In the nAc of $\mathrm{KI}$ a2 mice, the number of APs did not change in control condition, in the presence of a high concentration of ethanol, or in the presence of ethanol co-applied with STN $(F(2,24)=0.044$, $p=0.9569$, One-Way ANOVA, $n=10$. Fig. 2d). A similar result was observed in the curve of APs evoked by a series of depolarizing currents (0-400 pA, Fig. 2e). Ethanol $100 \mathrm{mM}$ (white circles) did not displace the control curve (white squares). The values for the rheobase in both conditions were also similar $(50 \mathrm{pA})$. These results suggest that the GlyR a2 subunit is important in keeping the inhibitory balance in the $\mathrm{nAc}$, and when the GlyR a2 subunit is mutated, ethanol no longer potentiates the inhibitory current, and therefore, no changes in neuronal excitability are observed.
The KI a2 mice have normal locomotor activity

Because $\mathrm{KI}$ a2 mice are a new mouse model, we evaluated the overall motor and neuromuscular activity before analyzing their response to ethanol. The $\mathrm{KI}$ a2 animals did not show any body or brain differences in morphology compared with the WT animals. The average body weight also did not differ between genotypes. For example, $\mathrm{Kl}$ a2 weight was $24.2 \pm 0.3$ and $23.8 \pm 0.3 \mathrm{~g}$ for WT male mice of $10-12$ weeks old $\left(t_{(99)}=0.944, p=0.3472\right.$, unpaired Student $t$ test, $n=48 \mathrm{KI}$ a2 and $n=53 \mathrm{WT}$, Supplemental Fig. 3A). Qualitative tests such as the grip test and the foot clenching behavior upon lifting by the tail are shown in Supplemental Fig. 3. The finding that the mice did not display foot clenching behavior is important because this is characteristic of other glycine $\mathrm{KI}$ a1 mouse lines where the GlyR function is impaired [36, 37].

Studies in male $\mathrm{KI}$ a2 mice showed that they displayed similar motor control characteristics as the WT mice on the accelerating Rotarod test (Supplemental Fig. 4A). After two days of testing, the $\mathrm{KI}$ a2 mice performed comparatively to the WT mice, finding no differences between the two genotypes $\left(F_{(1,23)}=3.072, p=\right.$ 0.0930 , Two-way repeated measurements ANOVA and Bonferroni post hoc test, $n=13 \mathrm{KI}$ a 2 and $n=12 \mathrm{WT}$ ), and both genotypes improved their performance from trial 1 to 15 , suggesting unimpaired motor learning ability $\left(F_{(14,322)}=10.95, p=0.0001\right.$, Two-way repeated measurements ANOVA, $n=13 \mathrm{KI}$ a2 and $n=$ 12 WT). We also analyzed the basal motor and exploratory activity of the $\mathrm{KI}$ a2 and WT mice with the open field test in control conditions. The distance traveled every $5 \mathrm{~min}$ was graphed in Fig. S4B ( $20 \mathrm{~min}$ total). Both WT and KI a2 male mice traveled the same distance, $2113 \pm 161 \mathrm{~cm}$ the first $5 \mathrm{~min}$ and $1394 \pm 165 \mathrm{~cm}$ the last $5 \mathrm{~min}$ of the test for $\mathrm{KI} \mathrm{a2} ; 2393 \pm 220 \mathrm{~cm}$ the first $5 \mathrm{~min}$ and $1595 \pm 148 \mathrm{~cm}$ the last $5 \mathrm{~min}$ of the test for WT mice $\left(F_{(1,80)}=\right.$ $1.865, p=0.1759$, Two-way ANOVA, $n=10 \mathrm{KI}$ a2 and $n=12 \mathrm{WT})$. The trajectory analysis showed that both groups equally passed through the center and the corners of the box (Fig. S4C). A higher time spent in the corners of the box versus the center could suggest the presence of anxiety-like behavior. However, both WT and $\mathrm{KI}$ a 2 mice spend the same amount of time in the center of the box, $31.6 \pm 5 \mathrm{~s}$ the first $5 \mathrm{~min}$ of the test for $\mathrm{KI}$ a 2 and $34.9 \pm 5 \mathrm{~s}$ 
A)

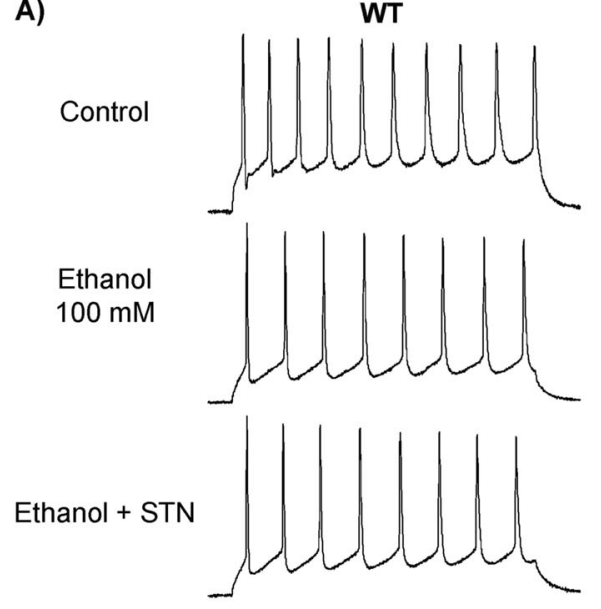

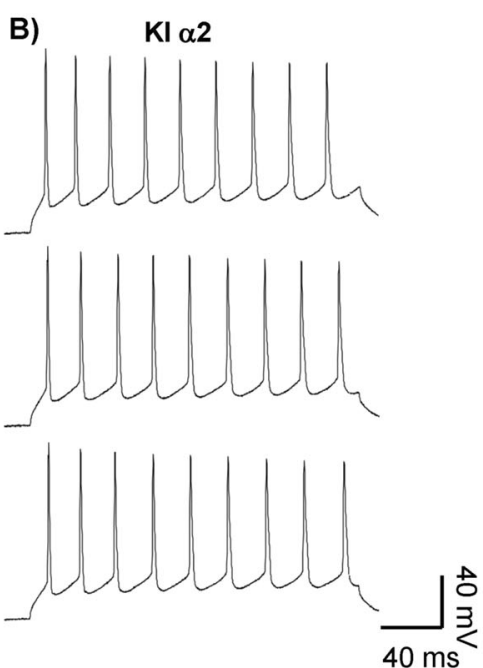

E)
C)

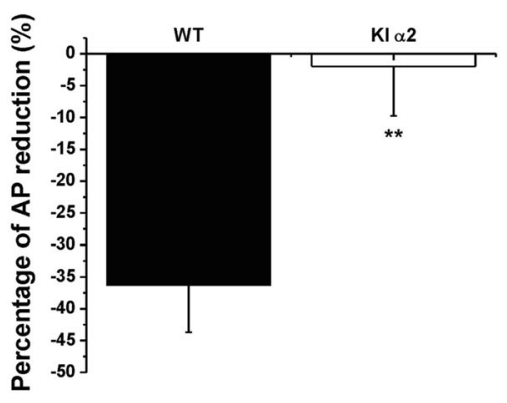

D)

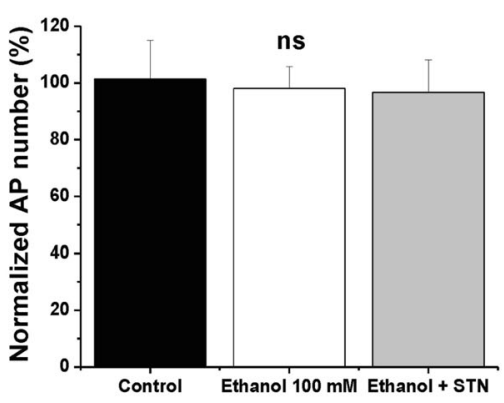

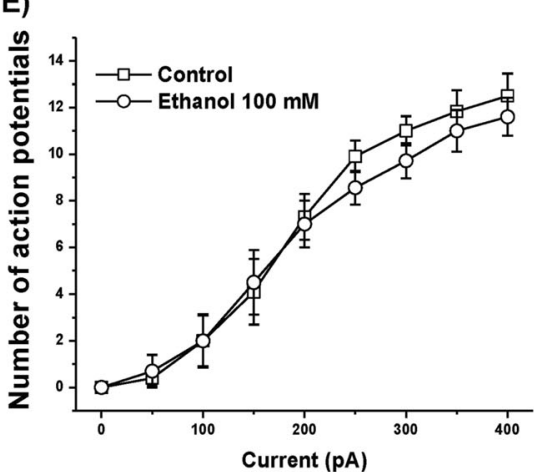

Fig. 2 Neuronal excitability in $\mathbf{n A c}$ from KI $\mathbf{a} \mathbf{2}$ mice is not affected by ethanol. a Representative traces of action potentials (AP) in neurons from the nAc of WT mice elicited with a current pulse of $200 \mathrm{pA}$ and $200 \mathrm{~ms}$ in control conditions and in the presence of $100 \mathrm{mM}$ ethanol, and ethanol co-applied with $4 \mu \mathrm{M}$ STN. b Representative traces of AP in neurons from the $\mathrm{nAc}$ of KI $\alpha 2$ mice elicited with a current pulse of $200 \mathrm{pA}$ and $200 \mathrm{~ms}$ in control conditions and in the presence of $100 \mathrm{mM}$ ethanol, and ethanol co-applied with $4 \mu \mathrm{M}$ STN. c Graph shows the percentage of AP reduction by $100 \mathrm{mM}$ ethanol in nAc from WT and KI $\alpha 2$ mice. $n=10$ for KI $\alpha 2$ and $n=8$ for WT. Data are mean \pm SEM, unpaired Student $t$ test ${ }^{* *} p<0.01$. d Graph summarizes the percentage of APs measured in nAc of KI $\alpha 2$ mice in the presence of 100 mM ethanol, and also in the presence of ethanol and STN. $n=10$. Data are mean \pm SEM, One-way ANOVA, ns. not significant. e The curves show the number of APs evoked with depolarizing currents from 0 to $400 \mathrm{pA}$. Ethanol $100 \mathrm{mM}$ did not reduce the number of APs recorded in control conditions.

the first 5 min of the test for WT mice $\left(F_{(1,80)}=0.01183, p=0.9137\right.$, Two-way ANOVA, $n=10 \mathrm{KI}$ a2 and $n=12 \mathrm{WT}$, Fig. S4D). These experiments show that male KI a2 mice have overall similar motor and anxiety-like behaviors as WT mice.

In addition, the accelerating rotarod test (Fig. S5A) showed that female $\mathrm{KI}$ a2 mice had unimpaired motor control, and performed the test similar to female WT $\left(F_{(1.22)}=1.458, p=0.2401\right.$, Two-way repeated measurements ANOVA and Bonferroni post hoc test, $n=15 \mathrm{KI}$ a2 and $n=9 \mathrm{WT}$ female mice). Data showed that both genotypes improved their performance from trial 1 to 15 $\left(F_{(14,308)}=7.050, p=0.0001\right.$, Two-way repeated measurements ANOVA and Bonferroni post hoc test, $n=15 \mathrm{KI}$ a2 and $n=9 \mathrm{WT}$ female mice). In the open field (Fig. S5B), female $\mathrm{KI}$ a2 mice traveled $2318 \pm 120 \mathrm{~cm}$ the first $5 \mathrm{~min}$ of the test, similar to female WT who traveled $2150 \pm 161 \mathrm{~cm}\left(F_{(1,100)}=2.115, p=0.1490\right.$, Twoway ANOVA and Bonferroni post hoc test, $n=18 \mathrm{KI}$ a2 and $n=9$ WT female mice). These results indicate that female $\mathrm{KI} \mathrm{a2}$, as males, have similar basal locomotor activity as WT.

The $\mathrm{KI}$ a2 mice recovered faster from high doses of ethanol We tested the response of these $\mathrm{KI}$ mice to administration of intoxicating doses of ethanol. The fixed-speed rotarod test was used to evaluate the effects of ethanol on motor skills and coordination. Mice were trained on a fixed-speed rotarod (7 rpm) to a maximum of $120 \mathrm{~s}$ for 3 days. On the third day, the mice received an i.p. injection of $2 \mathrm{~g} / \mathrm{kg}$ of ethanol and were tested on the rotarod every $15 \mathrm{~min}$ post injection until $90 \mathrm{~min}$. The data showed that male $\mathrm{KI}$ a2 mice recovered faster from the injection and performed better than the WT mice for almost every time point of the test. The male $\mathrm{KI}$ a2 mice reached the maximal $120 \mathrm{~s}$ on the rotarod at 75 min post injection, whereas WT mice took more than $90 \mathrm{~min}\left(F_{(1,22)}=4.950, p=0.0367\right.$, Two-way repeated measurements ANOVA and Bonferroni post hoc test, $n=12 \mathrm{KI}$ a2 and $n=12 \mathrm{WT}$; Fig. 3a). The faster recovery from motor impairment induced by ethanol was in agreement with the results from the loss of righting reflex (LORR) test in which male mice were injected with a sedative concentration of ethanol (3.5 $\mathrm{g} / \mathrm{kg}$ ) and placed in a supine position. Figure $3 \mathrm{~b}, \mathrm{c}$ shows the onset and duration of LORR, respectively. Again, $\mathrm{KI}$ a2 mice recovered faster from the ethanol injection and at $\sim 25 \mathrm{~min}$ they were able to right themselves to the normal prone position, while WT mice required more than $37 \mathrm{~min}\left(t_{(21)}=1.754, p=0.0941\right.$, unpaired Student $t$ test for onset of LORR; $t_{(21)}=3.799, p=0.0010$, unpaired Student $\mathrm{t}$ test for duration of LORR; $n=11 \mathrm{KI}$ a2 and $n=12 \mathrm{WT}$ ). These results indicate that the GlyR a2 subunit is important for ethanol-induced alterations in motor coordination and sedation. 
A)

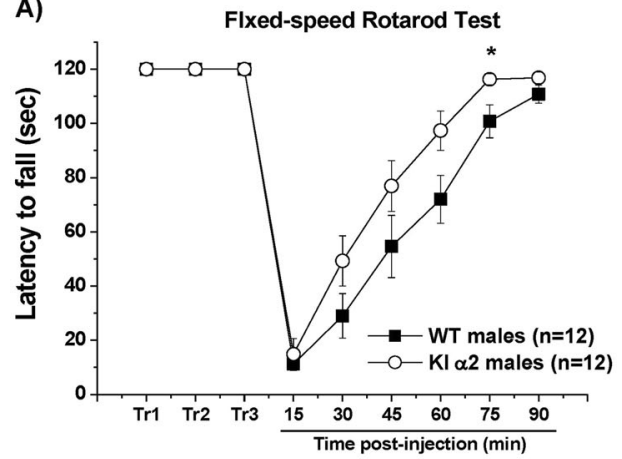

D)

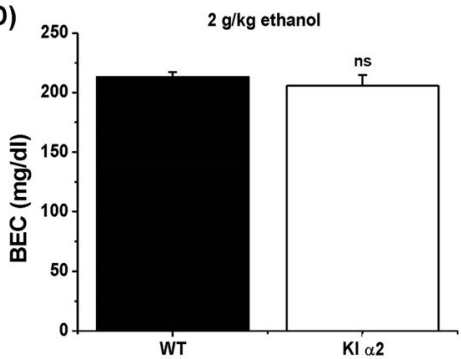

B)

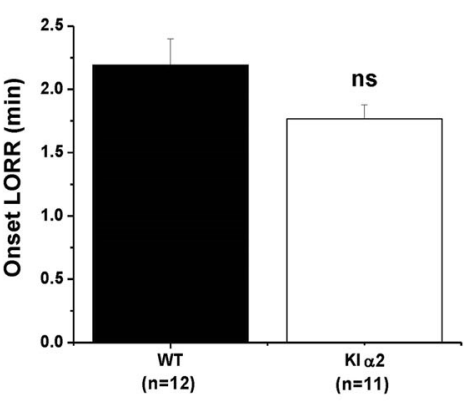

C)

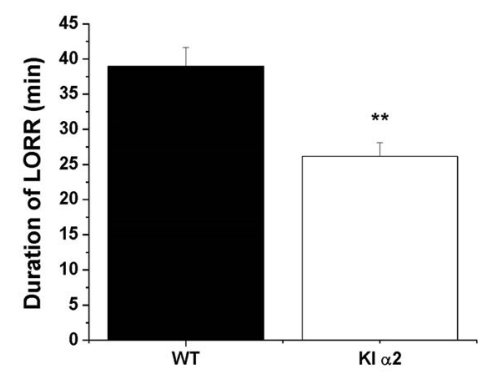

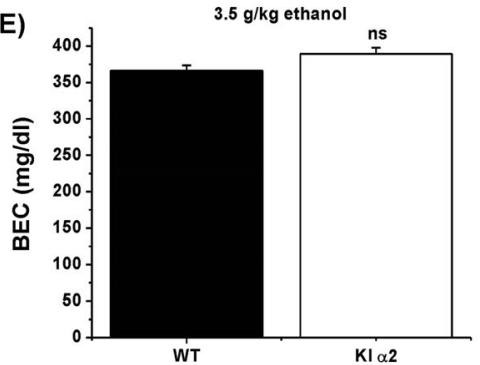

Fig. 3 Faster recovery from ethanol administration in KI a2 mice. a Fixed-speed Rotarod test. Male mice were tested for their motor skills after an ethanol injection of $2 \mathrm{~g} / \mathrm{kg}$ and registered the performance recorded in the rotarod at a fixed speed of $7 \mathrm{rpm}$. KI $\alpha 2 \mathrm{mice}$ reached the maximum $120 \mathrm{~s}$ at 75 min post injection. $n=12 \mathrm{KI} \alpha 2$ and $n=12 \mathrm{WT}$ mice. Data are mean \pm SEM, Two-way RM ANOVA and Bonferroni post hoc test ${ }^{*} p<0.05$. b Loss of righting reflex (LORR) assay. Male mice are given an i.p. injection with a sedative dose of ethanol (3.5 $\mathrm{g} / \mathrm{kg}$ ) and the time to lose the righting reflex (onset of LORR) and then c the time to acquire the righting reflex (duration of LORR) were recorded. KI $\alpha 2$ mice regain the righting reflex faster than WT mice. $n=11 \mathrm{KI} \alpha 2$ and $n=12 \mathrm{WT}$ mice. Data are mean \pm SEM, unpaired Student t test ${ }^{* *} p<0.01$, ns. not significant. d Blood ethanol concentration (BEC) $1 \mathrm{~h}$ after the injection of $2 \mathrm{~g} / \mathrm{kg}$ ethanol in KI $\alpha 2$ and WT mice. $n=8 \mathrm{KI} \alpha 2$ and $n=10 \mathrm{WT}$ mice. e BEC $1 \mathrm{~h}$ after the injection of $3.5 \mathrm{~g} / \mathrm{kg}$ ethanol in KI $\alpha 2$ and WT mice. $n=4 \mathrm{KI} \alpha 2$ and $n=8 \mathrm{WT}$ mice. Data are mean \pm SEM, unpaired Student $t$ test $p>0.05$, ns not significant.

In addition, to rule out changes in ethanol pharmacokinetics between the KI a2 and WT mice, we analyzed BEC of the mice $1 \mathrm{~h}$ after the i.p. injection of either 2 or $3.5 \mathrm{~g} / \mathrm{kg}$ ethanol. No significant differences were found between both genotypes. We obtained values of $206 \pm 9 \mathrm{mg} / \mathrm{dl}$ for $\mathrm{Kl}$ a2 and $213 \pm 4 \mathrm{mg} / \mathrm{dl}$ for WT mice after the injection of $2 \mathrm{~g} / \mathrm{kg}$ ethanol $\left(t_{(16)}=0.7849, p=0.4440\right.$, unpaired Student $t$ test; $n=8 \mathrm{KI}$ a2 and $n=10 \mathrm{WT}$ mice. Fig. 3d). After the injection of $3.5 \mathrm{~g} / \mathrm{kg}$ the values were $389 \pm 8 \mathrm{mg} / \mathrm{dl}$ for KI a2 and $366 \pm 7 \mathrm{mg} / \mathrm{dl}$ for WT mice $\left(t_{(10)}=1.932, p=0.0822\right.$, unpaired Student $t$ test; $n=4 \mathrm{KI}$ a2 and $n=8 \mathrm{WT}$ mice. Fig. 3e). It is important to point out that these BEC values were also similar to the ones found in other mice models $[38,39]$.

Additional studies in female $\mathrm{KI}$ a2 showed that they recovered faster after an ethanol injection of $2 \mathrm{~g} / \mathrm{kg}$ and reach $110 \mathrm{~s}$ in the fixed speed-rotarod assay at $\sim 45$ min post injection, whereas WT female mice require almost an hour to recover to that level $\left(F_{(1,18)}=1.656, \quad p=0.2145\right.$, Two-way repeated measurements ANOVA and Bonferroni post hoc test, ${ }^{*} p<0.05, n=11 \mathrm{KI}$ a2 and $n=9$ WT female mice; Fig. S5C). It is important to underscore that females, both $\mathrm{Kl}$ a2 and $\mathrm{WT}$, recovered faster than their male counterparts. Female WT and $\mathrm{KI}$ a2 mice were able to remain for $120 \mathrm{~s}$ on the rotarod at $60 \mathrm{~min}$ post injection. In comparison, it took considerably longer for male $\mathrm{KI} \alpha 2$ and $\mathrm{WT}$ mice to gain full control on the rotarod after the ethanol injection.

The $\mathrm{KI}$ a 2 mice presented increased binge drinking

We recently reported a role for the GlyR a1 subunit in ethanol consumption [18]. Since $a 1$ and $a 2$ subunits are expressed in $n A c$ [9], in the present study we wanted to determine if a2 also has a role in regulating ethanol consumption. For this, we used the DID assay to evaluate ethanol consumption in $\mathrm{KI}$ a2 and WT mice. This assay is widely used to detect binge levels of ethanol consumption [33]. The first three days mice are allowed to drink a $15 \%$ ethanol solution for $2 \mathrm{~h}$, and the 4th day mice can drink for $4 \mathrm{~h}$. Figure $4 \mathrm{a}$ shows that male $\mathrm{KI}$ a2 mice exhibited a binge-like drinking behavior, i.e. they started drinking high doses of ethanol on the first day and remained stable in their ethanol consumption for the next 2 days. This drinking pattern was different to that of male WT mice, that drank in an escalating fashion. On the 4th day, both animals drank similar amounts of ethanol, however, $\mathrm{KI}$ a2 mice values were higher $\left(F_{(1,93)}=19.86, p=0.0001\right.$, Two-way ANOVA and Bonferroni post hoc test ${ }^{* *} p<0.01$ at day $1,{ }^{*} p<0.05$ at day 2. $n=29 \mathrm{Kl}$ a2 and $n=12 \mathrm{WT}$ ). This higher intake was confirmed by measuring the BEC of these male mice after the test. Figure $4 \mathrm{~b}$ shows that $\mathrm{KI}$ a 2 mice displayed a higher $\mathrm{BEC}$ on the first day of consumption $(110 \mathrm{mg} / \mathrm{dl})$ compared with WT BEC values that did not go above $80 \mathrm{mg} / \mathrm{dl}\left(t_{(18)}=2.433, p=0.0256\right.$, unpaired Student $t$ test, $n=10 \mathrm{KI}$ a2 and $n=10 \mathrm{WT}$ ). In agreement with DID results in Fig. $4 \mathrm{a}$, after the $4 \mathrm{~h}$ of consumption on fourth day, BEC was also higher in $\mathrm{KI} \mathrm{a2,} \mathrm{but} \mathrm{not} \mathrm{significantly} \mathrm{different} \mathrm{from} \mathrm{WT}$ $\left(t_{(18)}=1.436, p=0.1607\right.$, unpaired Student $t$ test, $n=12 \mathrm{KI}$ a2 and $n=8$ WT; Fig. 4c). These results support the idea that GlyR a2 subunits have a role in regulating ethanol consumption.

It has been reported that female $\mathrm{C} 57 \mathrm{BL} / 6 \mathrm{~J}$ mice drink higher amounts of ethanol than male $[40,41]$. Similarly, KI a2 and WT females with a C57BL/6J genetic background started drinking a high quantity of ethanol $(3.42 \pm 0.2$ in $\mathrm{Kl}$ a2 versus $3.49 \pm 0.2 \mathrm{~g} / \mathrm{kg}$ in WT); with no statistical differences found between both genotypes $\left(F_{(1,40)}=0.4190, p=0.5211\right.$, Two-way ANOVA and Bonferroni post hoc test. $n=4 \mathrm{KI}$ a2 and $n=8 \mathrm{WT}$; Fig. S6A). Comparison of the ethanol consumption in male and female $\mathrm{KI}$ a2 (Fig. S6B) showed similar values but with slightly increased levels for females reaching $6.7 \pm 0.5 \mathrm{~g} / \mathrm{kg}$ compared with males that had $5.8 \pm 0.3 \mathrm{~g} / \mathrm{kg} \quad\left(F_{(1,73)}=4.908, \quad p=0.0298\right.$, Two-way ANOVA and Bonferroni post hoc test. $n=29$ male $\mathrm{Kl}$ a2 and $n=4$ female $\mathrm{KI}$ a2). 
A)

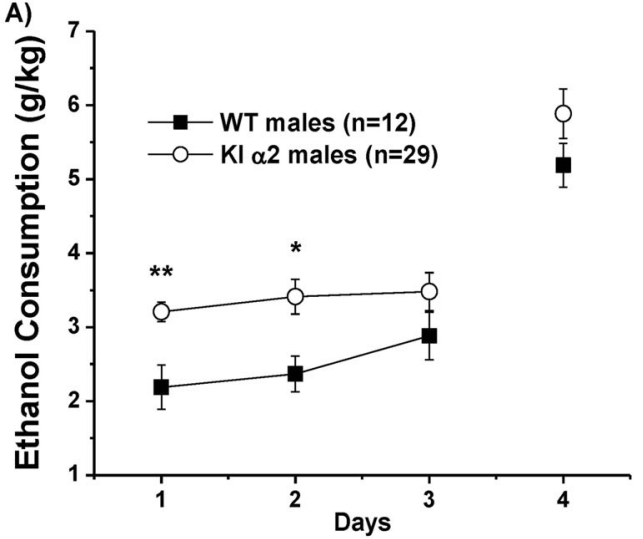

B)

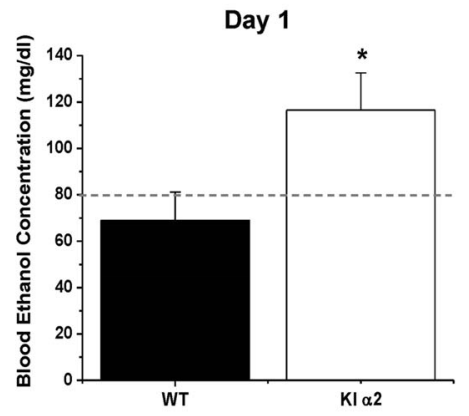

C)

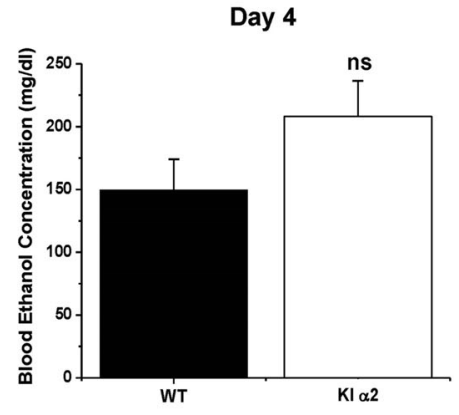

Fig. 4 Increased ethanol consumption in KI a2 mice. a Drinking in the dark test for ethanol consumption (DID). For 3 days, mice are able to drink a $15 \%$ ethanol solution for $2 \mathrm{~h}$ in the dark phase of the day. The fourth day, mice are able to drink for $4 \mathrm{~h}$. The consumption is measured in grams of ethanol per kilogram of weight $(\mathrm{g} / \mathrm{kg})$. Male $\mathrm{KI} \alpha 2$ mice drink more than WT mice in the firsts days of the test. $n=29 \mathrm{KI} \alpha 2$ and $n=$ 12 WT. Data are mean \pm SEM, Two-way ANOVA and Bonferroni post hoc test, ${ }^{* *} p<0.01,{ }^{*} p<0.05$. b Blood ethanol concentration (BEC) after ethanol consumption on the first day of the test. BEC from KI $\alpha 2$ mice is higher than from WT mice. $n=10 \mathrm{KI} \alpha 2$ and $n=10 \mathrm{WT}$. Data are mean $\pm \mathrm{SEM}$, unpaired Student $t$ test ${ }^{*} p<0.05$. c BEC after ethanol consumption on the fourth day of the test. $n=12 \mathrm{KI} \alpha 2$ and $n=8 \mathrm{WT}$. Data are mean \pm SEM, unpaired Student $t$ test $p>0.05$, ns not significant.

A)

B)
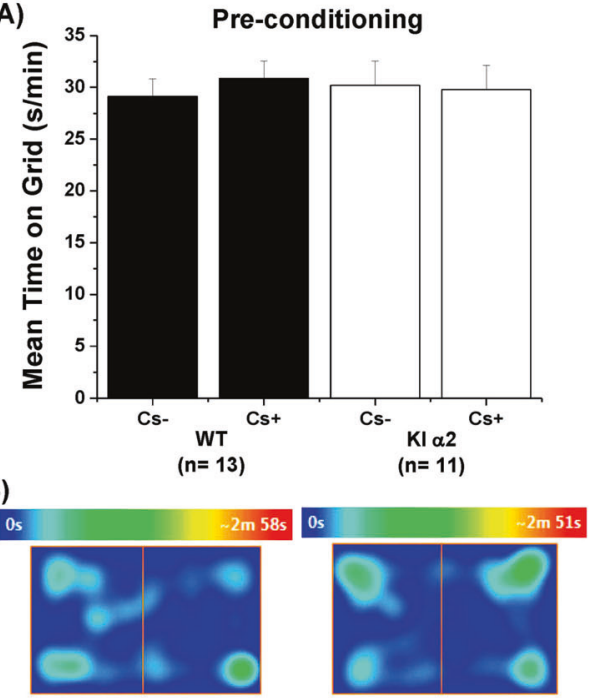

C)

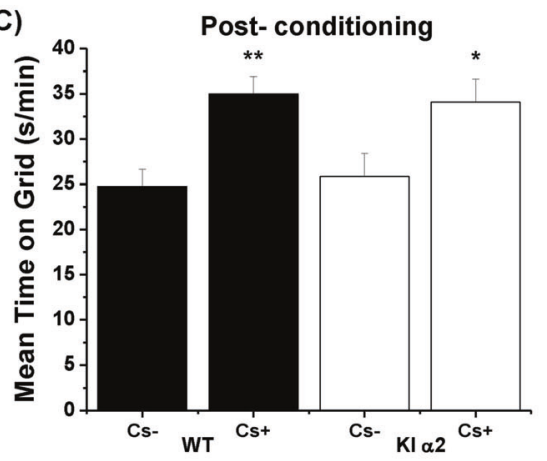

D)

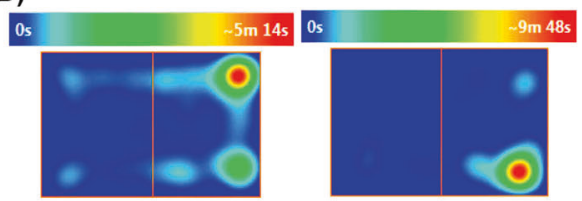

Fig. 5 Ethanol-conditioned place preference in $\mathbf{K I} \mathbf{a} \mathbf{2}$ and $\mathbf{W T}$ mice. a The graph shows the time spent in the floor associated with ethanol injection $(\mathrm{Cs}+)$ and saline injection ( $\mathrm{Cs}-)$ before the 8 sessions of conditioning of male WT and KI $\alpha 2$ mice. b Representative heat map of 15 min obtained from WT (left) and KI $\alpha 2$ (right) mice before the eight conditioning sessions. c The graph shows the time spent in the floor associated with ethanol injection ( $\mathrm{Cs}+$ ) and saline injection ( $\mathrm{Cs}-$ ) after the eight sessions of conditioning of WT and KI $\alpha 2$ mice. d Representative heat map of 15 min obtained from WT (left) and KI $\alpha 2$ (right) mice after the eight conditioning sessions. $n=11 \mathrm{KI} \alpha 2$ and $n=$ 13 WT mice. Data represent mean \pm SEM. Two-way ANOVA and Bonferroni post hoc test ${ }^{* *} p<0.01 ;{ }^{*} p<0.05$.

The KI $a 2$ and WT mice achieve similar ethanol-conditioned place preference

To evaluate the rewarding effects of ethanol, we used the conditioned place preference (CPP) test in male $\mathrm{KI}$ a2 and $\mathrm{WT}$ mice. Previous to the conditioning sessions, mice could explore both chambers and they spent similar amounts of time in both of them (Fig. 5a, b, WT in the left and KI $a 2$ in the right). Then, we performed eight conditioning sessions, in which we alternated an i.p. injection of $2 \mathrm{~g} / \mathrm{kg}$ of ethanol or a saline solution paired to a different floor having a specific grid size. On the final day of the test, mice chose which chamber they preferred; Cs+ was associated with ethanol and $\mathrm{Cs}-$ was associated with the saline solution. The seconds per minute spent on each type of floor are shown in Fig. 5c. The male KI a2 as well as the WT mice preferred the chamber associated with ethanol $\left(F_{(1,44)}=0.002585, p=\right.$
0.9597, Two-way ANOVA and Bonferroni post hoc test, ${ }^{* *} p<0.01$ and ${ }^{*} p<0.05, n=11 \mathrm{KI}$ a2 and $n=13 \mathrm{WT}$ ). These results can also be observed in the heat map in Fig. $5 d$, where both genotypes were conditioned to prefer the $\mathrm{Cs}+$ floor associated with ethanol.

\section{DISCUSSION}

Presence of GlyR a2 subunit in the CNS

The GlyR a2 subunit is highly expressed in early stages of CNS development [19]. In spinal cord and brain stem, this subunit is later replaced with a1 in adult rodents [21, 42]. Interestingly, although the presence of the a2 subunit has been reported in upper brain regions, its role in complex behaviors is still largely unknown [3]. A recent study showed the presence of the GlyR a 2 subunit in the dorsal striatum using a $\mathrm{KO}$ a 2 mouse 
model [8]; however, it is currently unknown if these GlyRs are sensitive to ethanol. Another study using a $\mathrm{KO}$ a 2 mouse model suggested that the GlyR a2 subunit played a role in ethanol consumption and preference [24]. Nevertheless, these results are somewhat confounded by potential subunit compensations that might occur during the development of these KO mice. Because the GlyR a2 subunit is important for the development of synaptic connections and migration of cortical interneurons $[22,43]$, changes during development are likely. Therefore, a KI mouse with normal GlyR, but insensitive to ethanol, appears to be an approach with less potential confounds.

Role of GlyRs in nAc

Previous studied have identified the presence of mRNA for GlyR $a 1, a 2$ and $\beta$ subunits in the $n A c$, a region important for addiction, including ethanol $[9,17]$. Also, a1 GlyRs are abundantly expressed in $n A c$ and regulate the excitability of MSNs [18]. Interestingly, electrophysiological recordings in $\mathrm{nAc}$ of the ethanol-insensitive a1 GlyR KI mice (KI a1 KK385-386AA) showed that some MSNs were still potentiated by ethanol, suggesting the presence of another GlyR subunit in this region [18]. In the present study, recordings of MSNs in brain slices and dissociated neurons of the $\mathrm{nAc}$ from the $\mathrm{KI}$ a2 mice showed similar results. Most WT neurons recorded were potentiated by ethanol, however, there was a large attenuation on the potentiation in $\mathrm{nAc}$ of $\mathrm{KI}$ a2 compared with WT mice (Fig. 1). In agreement, ethanol was unable to affect neuronal excitability in MSNs recorded in the KI a2 mice (Fig. 2), suggesting that the a 2 subunit is expressed and that plays a role in controlling excitability. Finally, the data support the notion of heterogeneity in terms of GlyR expression in the $\mathrm{nAc}$, and that both a1 and $\mathrm{a} 2$ GlyR subunits could be participating in the inhibitory regulation of this region.

The $\mathrm{KI}$ a2 mouse as a model for understanding ethanol-induced behaviors

Previous studies with recombinant receptors, prior to the generation of the $\mathrm{KI}$ a2 mice, showed that the basic amino acids KK385-386 in the LIL of the a1 GlyR subunit were critical for ethanol modulation through $G \beta \gamma$ [25]. A similar role of basic residues in LIL of the a2 GlyR subunit was proposed for ethanol potentiation [27]. Furthermore, these sites were specific for ethanol modulatory actions and not for other allosteric modulators [26]. In the present study, we report that the behavior of the $\mathrm{KI}$ a2 mice was overtly normal (Figs. S3 and S4) and this is relevant because several studies have linked mutations in the GLRA2 gene to behavioral disorders such as the autism spectrum disorder $[23,44,45]$. Also, the similar current density found in WT and KI mice in the nAc suggest that GlyR were equally expressed in this region (Fig. S1). Other results indicated that these GlyR present in the KI mice have a significant insensitivity to ethanol that is likely related to reduced levels of ataxia and sedation. Thus, the $\mathrm{KI}$ a2 mice recovered faster from the effects of ethanol on the fixedspeed rotarod and LORR assays, without changes in BEC levels compared with WT mice (Fig. 3). Overall, the data suggest that the presence of an ethanol-sensitive a2 GlyR in the brain plays a role in ethanol intoxication.

The $\mathrm{KI}$ a2 mice binge drink early during DID assay

According to the National Institute on Alcohol Abuse and Alcoholism (NIAAA), ethanol binge drinking is defined as ethanol consumption reaching more than $80 \mathrm{mg} / \mathrm{dl}$ of $\mathrm{BEC}$ in $2 \mathrm{~h}$ of drinking [46]. Interestingly, this pattern of consumption is common in adolescents and young adults, and has important medical consequences. For example, studies have proposed that this drinking pattern affects future drinking behaviors, as well as alterations in spatial learning and memory $[47,48]$. Our results showed that the $\mathrm{KI}$ a2 mice exhibited a binge drinking pattern of ethanol consumption. Male mice began the DID test drinking high amounts of ethanol that resulted in BECs $>110 \mathrm{mg} / \mathrm{dl}$ that were maintained for the next two days of testing. The early response of the $\mathrm{KI}$ a2 mice toward ethanol consumption is likely induced by an enhancement in the acquisition of the drinking behavior considering that the animals were naive to ethanol until this point. Based on this data, we propose that the increased consumption in the $\mathrm{Kl}$ a2 might be related to the dysregulation of the $n A c$ in the presence of ethanol and the reduced sedation induced by ethanol in these mice. A distinct pattern of consumption was observed in WT mice which had BEC levels of approximately $70 \mathrm{mg} / \mathrm{dl}$ on the first day of test and then the levels increased until the final day of DID where they reached values of around $150 \mathrm{mg} / \mathrm{dl}$ versus $200 \mathrm{mg} / \mathrm{dl}$ for KI a2 mice (Fig. 4). These results indicate that besides the GlyR a1 subunit, the a2 subunit also has a role in regulating ethanol consumption.

Interestingly, the impact of the $\mathrm{KI}$ mutation on female mice was not significant on their drinking pattern likely because the WT female genotype already drank high levels (Fig. S6). This agrees with previously reported data demonstrating that female C57 mice drink more alcohol than male mice $[40,41]$.

The $a 1$ and a2 GlyR subunits in the CNS are important for ethanolinduced behaviors

The present study aimed to understand the role of inhibitory GlyRs in the CNS. First, it is likely that potentiation of a1 and a2 subunits by ethanol produces sedation, thus, specific mutations lead to less sensitive forms of GlyRs, as shown in this study by reduced LORR and shorter times of motor incoordination induced by ethanol in the KI a2 mice. Nevertheless, we cannot rule out the contribution of other brain regions, besides the $\mathrm{nAc}$, that also might express GlyR and mediate sedation. For example, the prefrontal cortex and ventral tegmental area also express GlyRs, with the latter expressing fewer a 2 subunits than nAc (unpublished results). Second, the presence of GlyRs in the reward system (i.e., nAc) appears to be important for ethanol drinking because these GlyRs produce an inhibitory action in MSNs. Ethanol increases the inhibitory GlyRmediated tonic current and decreases the excitability of these neurons in the nAc [18]. Thus, it is suggested that regulation of the $\mathrm{nAc}$ and the reward system is important to prevent the development of ethanol addiction. As $n A c$ receives strong excitatory inputs from several brain regions, GlyRs provide a critical inhibition that is potentiated in the presence of ethanol (Fig. 2). For this reason, it is likely that in the KI mice the mutated GlyRs will be unable to counteract the excitation of the nAc and subsequently the reward system. This, in principle, explains why ethanol consumption is increased in $\alpha 1$ and $\alpha 2 \mathrm{KI}$ and they reach binge-like BECs [18]. This notion is in agreement with previous studies that showed that local administration of glycine or strychnine in the nAc alters the levels of dopamine in the $\mathrm{nAc}$ and ethanol consumption [14-16].

In conclusion, our study highlights the role of the a2 GlyR subunit in the adult brain and its involvement in mediating the inhibition of the $n A c$, in behavioral responses to ethanol and in ethanol consumption.

\section{FUNDING AND DISCLOSURE}

This work was supported by the National Institute on Alcohol Abuse and Alcoholism, NIH grants R01AA025718, AA10422, and AA020889. The authors declare no competing interests.

\section{ACKNOWLEDGEMENTS}

We thank Lauren Aguayo and Carolyn Ferguson for technical assistance and Carolina Benitez for expert veterinarian support. 


\section{AUTHOR CONTRIBUTIONS}

GEH created the KI mouse line. SG, LSM, AA designed, performed and analyzed the experiments. SG and LGA wrote the paper. DML and GEH discussed the paper. All authors revised, and approved the final version of the paper.

\section{ADDITIONAL INFORMATION}

Supplementary Information accompanies this paper at (https://doi.org/10.1038/ s41386-020-0689-9).

Publisher's note Springer Nature remains neutral with regard to jurisdictional claims in published maps and institutional affiliations.

\section{REFERENCES}

1. Burgos CF, Yévenes GE, Aguayo LG. Structure and pharmacologic modulation of inhibitory glycine receptors. Mol Pharmacol. 2016;90:318-25.

2. Lynch JW. Native glycine receptor subtypes and their physiological roles. Neuropharmacology. 2009;56:303-9.

3. Burgos CF, Muñoz B, Guzman L, Aguayo LG. Ethanol effects on glycinergic transmission: from molecular pharmacology to behavior responses. Pharmacol Res. 2015;101:18-29.

4. Dutertre S, Becker MC, Betz H. Inhibitory glycine receptors: an update. J Biol Chem. 2012;287:40216-23.

5. Salling MC, Harrison NL. Strychnine-sensitive glycine receptors on pyramidal neurons in layers II/III of the mouse prefrontal cortex are tonically activated. J Neurophysiol. 2014;112:1169-78.

6. Maguire EP, Mitchell EA, Greig SJ, Corteen N, Balfour D, Swinny J, et al. Extrasynaptic glycine receptors of rodent dorsal raphe serotonergic neurons: a sensitive target for ethanol. Neuropsychopharmacology. 2014;39:1232-44.

7. McCracken L, Lowes D, Salling M, Carreau-Vollmer C, Odean N, Blednov $Y$, et al. Glycine receptor $a_{3}$ and $a_{2}$ subunits mediate tonic and exogenous agonistinduced currents in forebrain. Proc Natl Acad Sci USA. 2017;114:E7179-E7186.

8. Molchanova S, Comhair J, Karadurmus D, Piccart E, Harvey R, Rigo JM, et al. Tonically active a2 subunit-containing glycine receptors regulate the excitability of striatal medium spiny neurons. Front Mol Neurosci. 2018;10:442.

9. Forstera B, Muñoz B, Lobo MK, Chandra R, Lovinger DM, Aguayo LG. Presence of ethanol-sensitive glycine receptors in medium spiny neurons in the mouse nucleus accumbens. J Physiol. 2017;595:5285-5300.

10. Muñoz B, Yevenes G, Forstera B, Lovinger DM, Aguayo LG. Presence of inhibitory glycinergic transmission in medium spiny neurons in the nucleus accumbens. Front Mol Neurosci. 2018;11:228.

11. Volkow ND, Morales M. The brain on drugs: from reward to addiction. Cell. 2015;162:712725.

12. Russo SJ, Nestler EJ. The brain reward circuitry in mood disorders. Nat Rev Neurosci. 2013;14:609-25.

13. Molander A, Söderpalm B. Accumbal strychnine-sensitive glycine receptors: an access point for ethanol to the brain reward system. Alcohol Clin Exp Res. 2005;29:27-37.

14. Lido $\mathrm{H}$, Ericson $\mathrm{M}$, Marston $\mathrm{H}$, Soderpalm B. A role for accumbal glycine receptors in modulation of dopamine release by the glycine transporter-1 inhibitor Org25935. Front Psychiatry. 2011;2:8.

15. Molander A, Söderpalm B. Glycine receptors regulate dopamine release in the rat nucleus accumbens. Alcohol: Clin Exp Res. 2005;29:17-26.

16. Molander A, Lof E, Stomberg R, Ericson M, Soderpalm B. Involvement of accumbal glycine receptors in the regulation of voluntary ethanol intake in the rat. Alcohol: Clin Exp Res. 2005;29:38-45.

17. Jonsson S, Morud J, Pickering C, Adermark L, Ericson M, Soderpalm B. Changes in glycine receptor subunit expression in forebrain regions of the Wistar rat over development. Brain Res. 2012;1446:12-21.

18. Muñoz B, Gallegos S, Peters C, Murath P, Lovinger DM, Homanics GE, et al. Influence of nonsynaptic a1 glycine receptors on ethanol consumption and place preference. Addict Biol. 2019;1-14.

19. Malosio M, Marqueze-Pouey B, Kuhse J, Betz H. Widespread expression of glycine receptor subunit mRNAs in the adult and developing rat brain. EMBO J. 1991;10:2401-9.

20. Aguayo LG, van Zundert B, Tapia JC, Carrasco M, Alvarez F. Changes on the properties of glycine receptors during neuronal development. Brain Res Brain Res Rev. 2004;47:33-45.

21. Watanabe $\mathrm{E}$, Akagi $\mathrm{H}$. Distribution patterns of mRNAs encoding glycine receptor channels in the developing rat spinal cord. Neurosci Res. 1995;23:377-82.

22. Avila A, Vidal P, Dear T, Harvey R, Rigo JM, Nguyen L. Glycine receptor a2 subunit activation promotes cortical interneuron migration. Cell Rep. 2013:4:738-50.
23. Pilorge M, Fassier C, Le Corronc H, Potey A, Bai J, De Gois S, et al. Genetic and functional analyses demonstrate a role for abnormal glycinergic signaling in autism. Mol Psychiatry. 2016;21:936-45.

24. Blednov Y, Benavidez J, Black M, Leiter C, Osterndorff-Kahanek E, Harris R. Glycine receptors containing a2 or a3 subunits regulate specific ethanol-mediated behaviors. J Pharmacol Exp Therapeutics. 2015;353:181-91.

25. Yevenes G, Moraga-Cid G, Guzman L, Haeger S, Oliveira L, Olate J, et al. Molecular determinants for $\mathrm{G}$ protein betagamma modulation of ionotropic glycine receptors. J Biol Chem. 2006;281:39300-7.

26. Yevenes G, Moraga-Cid G, Peoples R, Schmalzing G, Aguayo LG. A selective G betagamma-linked intracellular mechanism for modulation of a ligand-gated ion channel by ethanol. Proc Natl Acad Sci USA. 2008;105:20523-8.

27. Yevenes G, Moraga-Cid G, Avila A, Guzman L, Figueroa M, Peoples R, et al. Molecular requirements for ethanol differential allosteric modulation of glycine receptors based on selective Gbetagamma modulation. J Biol Chem. 2010;285:30203-13.

28. Fu Y, Sander J, Reyon D, Cascio V, Joung K. Improving CRISPR-Cas nuclease specificity using truncated guide RNAs. Nat Biotechnol. 2014;32:279-84.

29. Blednov Y, Borghese C, Ruiz C, Cullins M, Da Costa A, Osterndorff-Kahanek E, et al. Mutation of the inhibitory ethanol site in GABAA $\rho 1$ receptors promotes tolerance to ethanol-induced motor incoordination. Neuropharmacology. 2017;123: 201-9.

30. Mulligan M, Abreo T, Neuner S, Parks C, Watkins C, Houseal M, et al. Identification of a functional non-coding variant in the GABA A receptor a2 subunit of the C57BL/6J mouse reference genome: major implications for neuroscience research. Front Genet. 2019;10:188.

31. Wang $H$, Yang $H$, Shivalila $C$, Dawlaty $M$, Cheng A, Zhang F, et al. One-step generation of mice carrying mutations in multiple genes by CRISPR/Cas-mediated genome engineering. Cell. 2013;153:910-8.

32. Yang $H$, Wang $H$, Jaenisch $R$. Generating genetically modified mice using CRISPR/ Cas-mediated genome engineering. Nat Protoc. 2014;9:1956-68.

33. Thiele TE, Navarro M. "Drinking in the dark" (DID) procedures: a model of bingelike ethanol drinking in non-dependent mice. Alcohol. 2014;48:235-41.

34. Thiele TE, Crabbe JC, Boehm SL 2nd. "Drinking in the Dark" (DID): a simple mouse model of binge-like alcohol intake. Curr Protoc Neurosci. 2014;68:9 49 1-12.

35. Cunningham CL, Gremel CM, Groblewski PA. Drug-induced conditioned place preference and aversion in mice. Nat Protoc. 2006;1:1662-70.

36. Findlay G, Phelan R, Roberts M, Homanics G, Bergeson S, Lopreato G, et al. Glycine receptor knock-in mice and hyperekplexia-like phenotypes: comparisons with the null mutant. J Neurosci. 2003:23:8051-9.

37. Borhese C, Blednov Y, Quan Y, lyer S, Xiong W, Mihic S, et al. Characterization of two mutations, M287L and Q266l, in the a1 glycine receptor subunit that modify sensitivity to alcohols. J Pharmacol Exp Therapeutics. 2012;340:304-16.

38. Stevenson RA, Besheer J, Hodge CW. Comparison of ethanol locomotor sensitization in adolescent and adult DBA/2J mice. Psychopharmacology. 2008;197: 361-70.

39. Aguayo LG, Castro P, Mariqueo T, Muñoz B, Xiong W, Zhang L, et al. Altered sedative effects of ethanol in mice with a1 glycine receptor subunits that are insensitive to $G \beta \gamma$ modulation. Neuropsychopharmacology. 2014;39: 2538-48.

40. Middaugh L, Kelley B, Bandy, AL, McGroarty K. Ethanol consumption by C57BL/6 mice influence of gender and procedural variables. Alcohol. 1999;17: 175-83.

41. Satta R, Hilderbrand ER, Lasek AW. Ovarian hormones contribute to high levels of binge-like drinking by female mice. Alcohol: Clin Exp Res. 2018;42:286-94.

42. Singer J, Talley E, Bayliss D, Berger A. Development of glycinergic synaptic transmission to rat brain stem motoneurons. J Neurophysiol. 1998;80:2608-20.

43. Morelli G, Avila A, Ravanidis S, Aourz N, Neve R, Smolders I, et al. Cerebral cortical circuitry formation requires functional glycine receptors. Cereb Cortex (1991). 2017:27:1863-77.

44. Piton A, Gauthier J, Hamdan F, Lafreniere R, Yang Y, Henrion E, et al. Systematic resequencing of $X$-chromosome synaptic genes in autism spectrum disorder and schizophrenia. Mol Psychiatry. 2011;16:867-80.

45. Zhang Y, Ho T, Harvey R, Lynch J, Keramidas A. Structure-function analysis of the GlyR a2 subunit autism mutation p.R323L reveals a gain-of-function. Front Mol Neurosci. 2017;10:158.

46. NIAAA. NIAAA council approves definition of binge drinking. NIAAA Newslett. 2004;3:3.

47. Younis R, Wolstenholme J, Bagdas D, Bettinger J, Miles M, Damaj M. Adolescent but not adult ethanol binge drinking modulates ethanol behavioral effects in mice later in life. Pharmacol Biochem Behav. 2019;184:172740.

48. Wagner JL, Zhou FC, Goodlett CR. Effects of one- and three-day binge alcohol exposure in neonatal C57BL/6 mice on spatial learning and memory in adolescence and adulthood. Alcohol. 2014;48:99-111. 